\title{
Possible functions of a population of descending neurons in the honeybee's visuo-motor pathway
}

\author{
NJ Bidwell *, LJ Goodman ** \\ School of Biological Sciences, Queen Mary and Westfield College, \\ Mile End Rd, London E1 4 ND, UK
}

(Received 7 December 1992; accepted 30 March 1993)

\begin{abstract}
Summary - An identified population of honeybee descending neurons (DNs) responds to wide-field motion over the compound eyes. They give non-habituating, directionally selective responses which adapt to continued motion. Contrast sensitivity functions show the responses depend on luminance, contrast, spatial and temporal frequency. The distribution of the DNs' outputs in the thoracic ganglia is consistent with changes in muscular activity required for particular compensatory movements. These features suggest the DNs lie along the optomotor pathway. The DNs' responses have different time-courses. This might reflect distinctions in their putative inputs and between pathways implicated in different aspects of visually mediated flight control. The responses of horizontal DNs to contraction and expansion and to unidirectional motion were compared revealing differences in the way they integrate the monocular components of binocular flow-fields and how velocity and spatial structure effects this integration. It is possible the DNs are convergence site(s) for substrates underlying different behaviours each triggered by specific optical flow templates.
\end{abstract}

descending neuron / vision / motion sensitivity / directional selectivity

\section{INTRODUCTION}

The honeybee's ability to discriminate between colours (von Frisch, 1914; Menzel, 1967) and shapes (Anderson, 1972) and perceive depth (Srinivasan et al, 1989) and distance (Kirchner and Srinivasan, 1989; Srinivasan et al, 1991) is impressive. Contemporary analysis of the honey- bee's extensive list of visually mediated free-flight behaviours is making us increasingly aware of the sophistication of the underlying visual system. Like most diurnal flying insects the honeybee's natural visual environment is an opulent assortment of optical information. The large visual field of her compound eyes is filled with an array of spectral wavelengths and

\footnotetext{
* Present address: Sussex Centre for Neuroscience, School of Biological Sciences, University of Sussex, Brighton BN1 9QG.

** Correspondence and reprints.
} 
luminance modulations, all distributed nonuniformly and moving over her eyes in different directions relative to her body as she flies. From this veritable cacophany of visual information the honeybee is able to extract and process that information which is relevant to the control of her flight course and speed, both rapidly and accurately. There is currently much interest in the mechanisms which underlie the extraction of different types of visual information in the insect visual pathway. In this paper we consider a population of neurons involved in the process in the honeybee and examine the way in which certain sorts of information are simplified before being transmitted to the motor centres.

Wehner (1987) pointed out that information is filtered by insects at the most peripheral level in a way that is matched to the solution of a particular task. Behavioural evidence suggests that the honeybee's visual system simplifies its task by separating colour from motion information (eg Lehrer et al, 1990). Certainly many motion-sensitive behaviours in the bee such as optomotor responses (Kaiser and Liske, 1974; Kaiser, 1975); movementavoidance responses (Srinivasan and Lehrer, 1984) and aspects of tracking moving targets (Zhang et al, 1990) are chromatically independent. This duality in the honeybee has been compared with the situation in vertebrates (eg Zhang et al, 1990; Lehrer, 1991) where perception of motion is believed to be subserved by the colourblind magnocellular pathway (Livingston and Hubel, 1987). Recent neuroanatomical studies by Strausfeld and lee (1991) support the presence of 2 parailel retinotopic pathways in the insect optic lobe which appear to arise from each ommatidium within the retina. These authors suggest that this could form the basis of 2 independent pathways for colour and for motion in insects. The task of the pathway which concerns us in this article is that of guiding and stabilising the honeybee's flight upon the basis of motion information.

We have physiologically characterised a large number of identified interneurons which descend from the brain to the thoracic motor centres of the bee (Fletcher et al, 1984; Goodman et al, 1987, 1990, 1991; Ibbotson, 1990, 1991; Ibbotson and Goodman, 1990; Bidwell, 1992). Analysis of the response characteristics of these descending neurons (DNs) shows that they give directionally selective responses to widefield motion over the compound eyes and suggests that they might represent one of the final stages of a motion processing pathway. They thus provide a tool with which to examine the way the different parameters that influence motion processing have been filtered and matched to the requirements of flight control.

The response properties of the neurons were examined by stimulating the bee using either mechanically moved squarewave gratings or electronically generated sine-wave gratings ("Constable" image generator, Cardiff Visual Systems) presented on an $X-Y$ display monitor (Tectronix 608). Specific details of the stimulating regimes for each experiment are included in the legends of appropriate figures. Following intracellular recordings the cells were identified by iontophorectic injection of dye, either cobalt chloride (Goodman et al, 1990, 1991; Ibbotson and Goodman, 1990; Ibbotson, 1991; or Lucifer yellow (Bidwell, 1992).

\section{THE DIRECTIONAL SELECTIVITY OF THE DNs}

The response of the bee DNs is maximal for motion in one direction, the preferred direction (eg figs $2 a, 3 a, 4 a$ ). Like the responses of directionally selective (DS) cells throughout the insect visuo-motor 
pathway (eg fly lobula plate neurons: Hausen, 1984; motor neurons: Milde and Strausfeld, 1990) the response of the DNs gradually declines as the direction of motion subtends a larger angle with the preferred direction. The peak responses of the DNs tend to occur for motion along the vertical or the horizontal and their preferred directions can be broadly defined as: progressive, regressive, upwards or downwards motion (eg, figs 1a-d). This physiological division into vertically or horizontally tuned cells can be correlated with certain anatomical characteristics of the cells within the brain, morphologically distinct DNs being grouped together on the
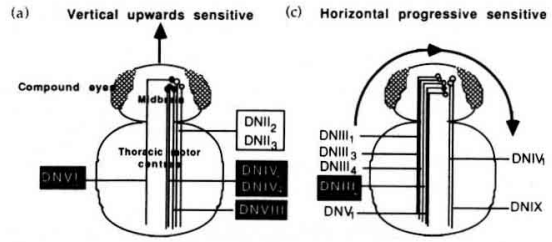

(b)

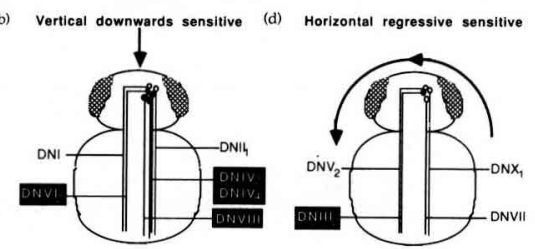

Fig 1. A diagrammatic representation of the neurons maximally excited by (a) upwards; (b) downwards; (c) progressive; and (d) regressive wide-field motion. The honeybee is viewed from above. The somata of neurons which respond exclusively to one direction of motion over the frontal or lateral regions of the eyes are represented by empty circles. The somata of neurons which respond to more than one direction of motion over the frontal or lateral regions of the eyes are shown by filled circles and shaded annotations. Only one cell of each pair of descending neurons is shown. Some of the neurons descend to the thorax on the same side of the body as the side in which the soma lies (ie ipsilaterally; eg $\mathrm{DNII}_{2}-\mathrm{a}$ ). Other neurons descend to the thorax on the opposite side to the side of the body in which the soma lies (ie contralaterally; eg DNIII - c). basis of the location of their dendritic fields in the midbrain neuropile (eg lbbotson, 1990). Two discrete populations of DNs (DN clusters) have been identified. The pri-
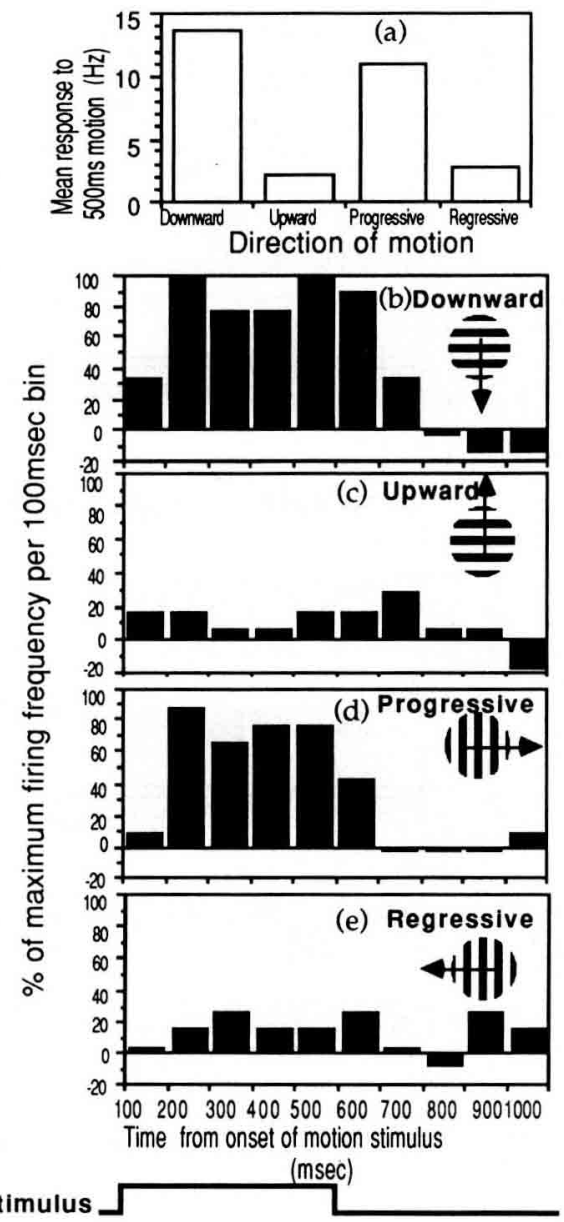

Fig 2. The motion induced response of $\mathrm{DNII}_{1}$. Since-wave gratings were moved in each of $4 \mathrm{di}$ rections: downwards, upwards, progressive and regressive for $500 \mathrm{~ms}$ over the frontal regions of the eyes. Over $500 \mathrm{~ms}$ stimulation the grating elicits the highest rate of firing relative to baseline frequency when it moves downwards (a). When spikes were counted in $100 \mathrm{~ms}$ bins from the onset of stimulation the maximum spike frequency per $100 \mathrm{~ms}$ bin occurs $100-200 \mathrm{~ms}$ after the onset of stimulus $(b-e)$. 

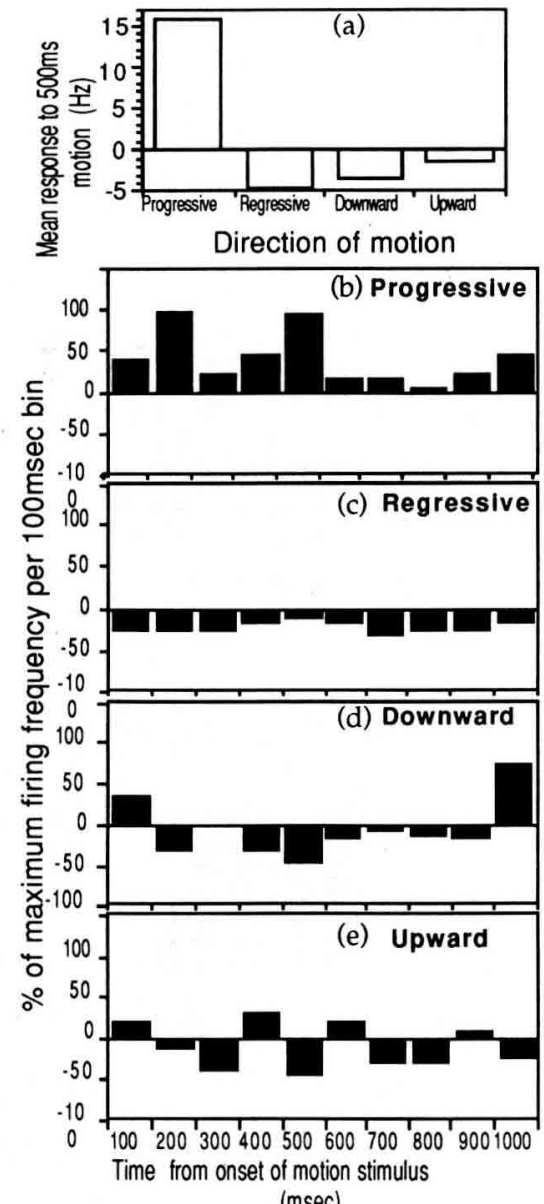

(msec)
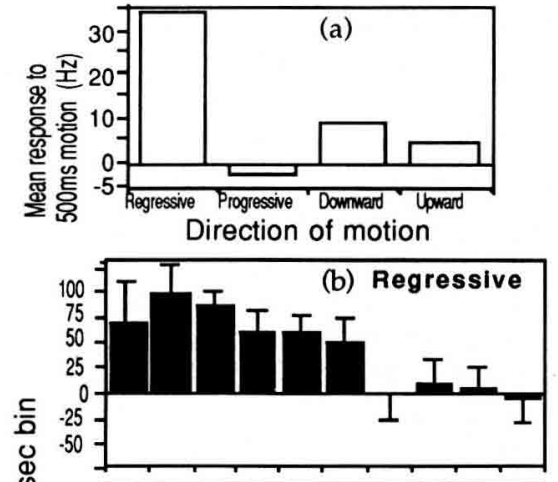

है

100

100
75
50

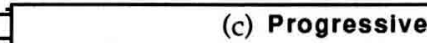

高
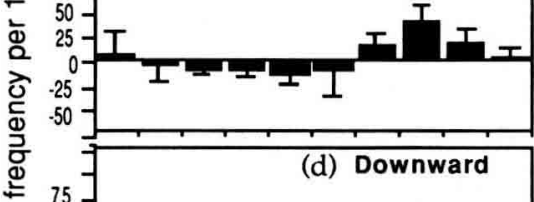

75

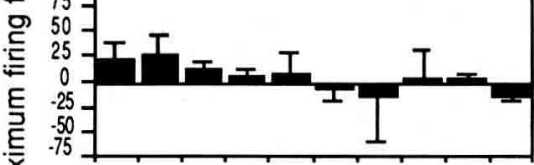

ฮู

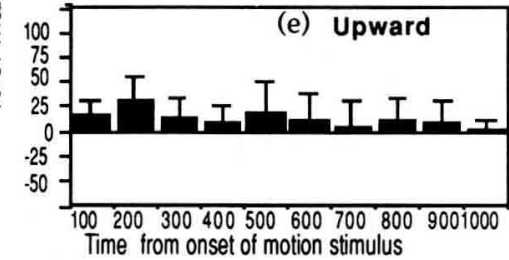

(msec)

stimulus

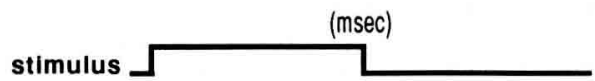

Fig 3. The motion-induced response of $\mathrm{DNIII}_{3}$. Since-wave gratings were moved in each of $4 \mathrm{di}$ rections as described for figure 2 . Over $500 \mathrm{~ms}$ the grating elicits the highest rate of firing relative to baseline frequency when it moves progressively (a). The maximum spike frequency per 100 msec bin for DNIII3 occurs 100-200 ms after the onset of the stimulus (b-e). Mean values were calculated from the response of 2 cells.

Fig 4. The motion-induced response of DNVII. Sine-wave gratings were moved in each of $4 \mathrm{di}$ rections as described for figure 2 . Over $500 \mathrm{~ms}$ the grating elicits the highest rate of firing relative to baseline frequency when it moves regressively (a). The maximum spike frequency per $100 \mathrm{~ms}$ bin for DNVII occurs $100-200 \mathrm{~ms}$ atter the onset of the stimulus (b-e). Error bars show the SD for 4 DNVII cells. 
mary dendritic fields of DNs in the first cluster are located in the postero-lateral deuto-tritocerebrum and overlap with the terminals of lobula neurons which have travelled in posterior optic tract I (POT I). In the second cluster the dendritic arborisations of the DNs are restricted to the postero-dorsal deutocerebrum in the vicinity of the axon terminals of lobula neurons in posterior optic tract II (POT II). In the fly separate mid-brain projection centres have been shown to be associated with the terminals of either horizontally or vertically sensitive lobula neurons (Hengstenberg et al, 1982). The terminals of vertically sensitive lobula neurons connect with the dendrites of a cluster of vertically tuned descending cells and the horizontally sensitive lobula neurons are associated with the dendritic branches of horizontallytuned descending neurons (Eckert, 1981; Strausfeld, 1984; Strausfeld et al, 1987). An analogous segregation of directional selectivity appears to exist in the honeybee as DNs within each cluster associated with POT I or POT II share a common preference for either horizontal or vertical motion (lbbotson, 1990). This division corresponds with that proposed for lobula neurons which travel along POT I (Hertel and Maronde, 1987) and POT II (Ibbotson, 1990) respectively.

The convergence of directionally specific motion information at targets in the brain may have 2 potential functions, both of which are of interest in the context of operations at the lobula-DN interface. One function of directionally-specific targets in the brain might be to maintain vertical and horizontal selectivity. Thus targets simply act as a funnel into the DNs for information of the same directional persuasion. Ibbotson (1989) identified 2 morphological features which distinguish the vertically tuned from the horizontally tuned DNs. A faster visuo-motor connection is inferred by the larger axonal diameter, $10-15 \mu \mathrm{m}$, of verti- cally sensitive DNs. Ibbotson also proposed a more direct visuo-motor connection based on the location and structure of the terminal branches of vertically sensitive DNs in the thoracic motor centres. The vertical DNs have short, stubby branches in the latero-dorsal neurophile which might provide a direct synaptic contact with the dendritic trunks of direct flight motor neurons. The more ventrally located thin, beaded terminal fibres of the horizontal DNs spread diffusely throughout the ganglia. This suggests that horizontal DNs connect to the dendritic branches of interneurons of the premotor circuitry, which might correspond to a less direct route with an extra level of processing. Parallel flow of vertical and horizontal information to the DNs permits the distinction between direct and indirect transfer from them. This distinction might be adapted to suit the requirement of the motor output. For example, fewer synaptic stages in the vertical network would reduce transmission time for input used to stabilise flight. Concomitantly, more processing stages in the horizontal network might refine the accuracy of signals used in the precise control of flight direction and speed.

A second potential function for vertical and horizontal parallel flow is the possibility of flexible integration of sensory data. This might include incorporating the outputs of both the vertical and horizontal systems to enhance the specificity of the responses of some DNs. The specificity of the DNs directionally selective responses is wide ranging. Take for example the specificity of the responses of $2 \mathrm{DNs}$ sensitive to vertical motion (see fig 1b). The firing frequency of DNI in response to downwards motion is 10-fold higher than its firing frequency in response to horizontal motion. Less specific is the response of another vertical cell, DNII ${ }_{1}$, which responds only slightly more (1.2-fold) to downwards motion than horizontal motion. A correla- 
tion between the relative size of the DNs' responses to vertical and horizontal information and the period of time taken for them to achieve their maximum rate of firing suggests that those cells which convey more directionally specific information require a longer time to arrive at their maximum response level (fig $2 b$ ). By counting spikes in $100 \mathrm{~ms}$ bins from the onset of the movement stimulus, a crude estimate of the time taken to reach maximum firing frequency was extrapolated. Of the 2 vertically tuned cells mentioned above, DNI takes $248 \mathrm{~ms}$ to reach $75 \%$ of its maximum firing frequency whilst $\mathrm{DNII}_{1}$ takes only 138 ms to reach $75 \%$ of its maximum firing frequency. The correlation also holds true for the horizontally sensitive cells. For instance, the time required to reach $75 \%$ of the maximum rate of firing by 2 regressive sensitive cells, DNVII and $\mathrm{DNIII}_{3}$ is $137 \mathrm{~ms}$ and $167 \mathrm{~ms}$ respectively. DNVII responds to horizontal motion twice as much as it does to vertical motion, whilst DNIII responds with excitation to progressive motion only. The various degrees of directional specificity suggest that a precise signal obtained by 'filtering' is not a functional prerequisite for motor output and in certain circumstances would perhaps be a disadvantage. Specificity in the DNs seems to demand time and it may be that for some signals accuracy is accomplished at a later stage (eg at the thoracic motor centre).

\section{HOW IS THE INFORMATION SIGNALLED BY THE DNS RELATED TO THE LUMINANCE CONTRAST OF THE BEES SURROUNDINGS?}

The visual system maintains invariance in conditions of varying illumination by responding to contrast. Surfaces absorb or reflect a constant fraction of incident light, so that the relative intensities of objects are constant, provided they are uniformly illuminated. The response (firing frequency) of the DNs increases with the luminance contrast of a moving sine-wave grat-

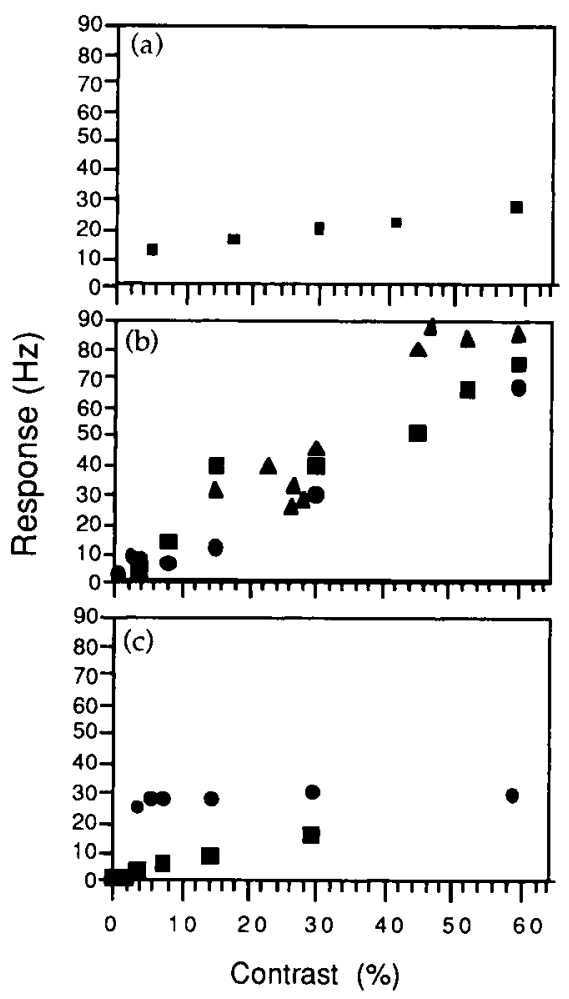

Fig 5. Contrast response functions for the DNs. (a) The averaged response of $20 \mathrm{DNs}$ to gratings moving in each cell's preferred direction over the lateral regions of the field. The mean luminance of the grating was $0.02 \mathrm{~cd} / \mathrm{M}^{2}$ and its drift generated a temporal frequency of $11 \mathrm{~Hz}$. (b) The response of DNIII1 (filled squares); DNI (filled circles) and unidentified vertical cell (filled triangles) to motion in their preferred directions over the frontal regions of the field. The mean luminance of the grating was $2.0 \mathrm{~cd} / \mathrm{M}^{2}$ and its drift generated a temporal frequency of $11 \mathrm{~Hz}$. (c) The response of $\mathrm{DNIII}_{2}$ to motion in its preferred direction (upward: circles) and non-preferred direction (progressive: squares) over the frontal regions of the compound eyes. The mean luminance of the grating was $2.0 \mathrm{~cd} / \mathrm{M}^{2}$ and its drift generated a temporal frequency of $11 \mathrm{~Hz}$. 
ing (fig $5 \mathrm{a}-\mathrm{c}$ ). The absolute responses in some of the DNs increases approximately in proportion to $\partial \mathrm{l}^{2}$ (fig $5 \mathrm{a}, 5 \mathrm{~b}$ ) but this is not true for all of them. The shape of the contrast-response function (firing frequency versus contrast) in the DNs depends upon background luminance. When adapted to lower luminances the contrast response approximates to a straight line with a shallow slope (fig 5a), but when adapted to higher luminance the contrast-response function becomes steeper (fig 5b).

The luminance contrast which gives visual texture to the panorama has a wide range. However, the range of contrasts produced by objects in habitats uncontaminated by human artefacts is relatively small. By sampling points in a number of images, using a scanner with the same angular and spectral sensitivity as a fly's eye, Laughlin (1981) found that their average contrast was $40 \%$, with the majority of contrasts $<50 \%$. The visual system exploits the information most commonly encoutered in scenes, at least in the natural environment. Thus the most efficient operation of the motion detection system has evolved by devoting its dynamic range to the lower end of the distribution of contrasts in natural scenes at the expense of coding the rare high contrasts which are associated with specular relections and light sources. Like the contrast-response curve of lamina monopolar cells (LMCs) in the fly (Laughlin et al, 1987) the contrastresponse curve of the majority of the DNs is non-linear with a characteristic sigmoidal shape. The dynamic range of the DNs in the bee also resembles those of other neurons higher in the visual pathway, such as $\mathrm{H} 1$ in the fly lobula (Dubs, 1982), from which one can infer that the exploitation of the statistical distributions of contrast in natural scenes is an ubiquitous tool in insect motion pathways.

Interneurons such as the DNs and the behavioural responses they drive are high-
Iy sensitive to moving gratings composed of very low contrast $(\Delta \mathrm{l} /$ mean l) elements. For moving gratings at contrast values $<3-4 \%$ the walking responses of Drosophila (Heisenberg and Buchner, 1977) and flight responses of Musca (McCann and MacGinitie, 1965) approximate to a parabola which indicates a dependence on $\left.\Delta\right|^{2}$. The exquisite sensitivity to small fluctuations of low contrasts of both motioninduced behaviour and the bee DNs exemplifies the conservation of the initial signal at all levels of the pathway.

\section{WHAT RANGE OF SPATIAL FREQUENCIES ARE USED TO SIGNAL MOVEMENT OF THE HONEYBEE'S SURROUNDINGS?}

To provide a robust neural representation of the retinal stimulus, only those signals that provide a high signal:noise ratio and represent rich motion cues are transmitted. Filtering, either peripherally or as a consequence of the motion detecting process, thus determines the information that is used to control motion-induced behaviour. Sine-wave gratings are used to examine the spatial frequency response of the visual system or some part of it in terms of the spatial contrast sensitivity function (CSF). The CSF can reveal which spatial frequencies, if any, are filtered from optical signals, and has been used to infer the processing level at which filtering might occur (eg Srinivasan and Dvorak, 1980). Contrast sensitivity is measured by determining the minimum amount of contrast (threshold contrast) required of a grating to evoke a significant motion response. Contrast sensitivity is the reciprocal of threshold contrast and varies with sinusoidal spatial frequency. The CSFs shown here were established by locating the contrast of a grating of defined spatial frequency where a DN displayed significant directional selectivity by differentiat- 
ing between null and preferred motion using a modified binary bracketing routine (Tyrell and Owens, 1988).

All the CSFs established for the bee DNs at higher luminance peak in the range 0.03-0.06 cpd when the temporal frequency generated by the moving grating was $11 \mathrm{~Hz}$ (fig 6a). At lower luminances, over the lateral regions of the visual field, the

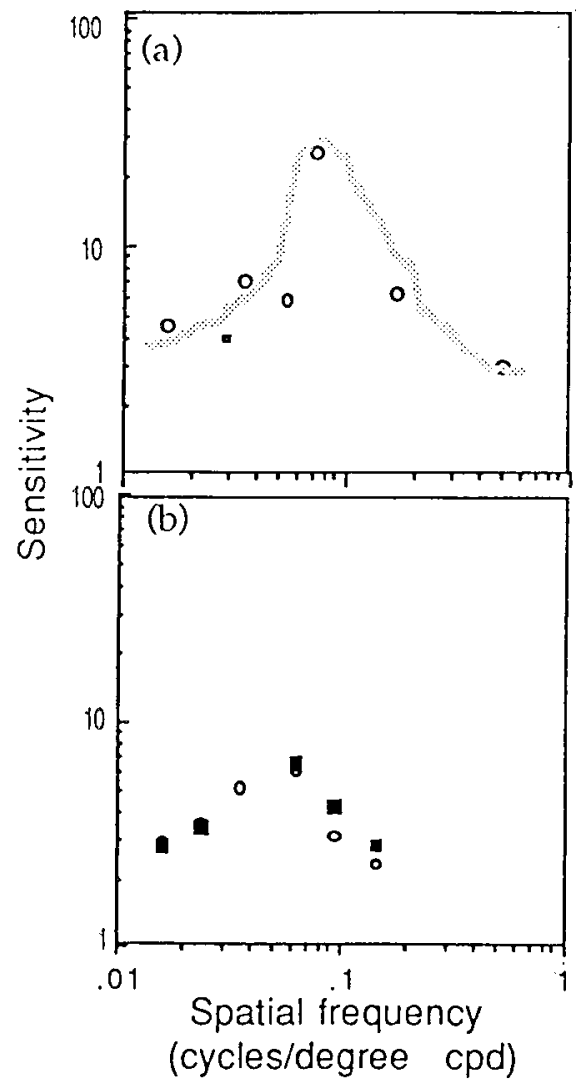

Fig 6. Contrast sensitivity functions for (a) $\mathrm{DNH}_{2}$ to gratings of mean luminance $2.0 \mathrm{~cd} / \mathrm{M}^{2} \mathrm{mov}-$ ing over the frontal regions of the field and (b) for cells sensitive to progessive (filled squares) and regressive (open circles) to gratings of mean luminance $0.2 \mathrm{~cd} / \mathrm{M}^{2}$ moving over the lateral regions of the field. The spatial frequency of the moving grating was measured in cycles/ degree of visual angle (cpd). sensitivity peak shifts towards lower values of spatial frequency as shown for 2 horizontally sensitive cells (fig 6b). The DN's contrast sensitivity as a function of spatial frequency is approximately within the same range as cells higher in the insect visual pathway such as medulla cells terminating in the midbrain of the butterfly, Papillio (Maddess et al, 1991) and the lobula plate giant cells terminating in the mid-brain of the flies Musca and Lucilia (Dvorak et al, 1980; Srinivasan and Dvorak, 1980). The spatial frequency specificity of the DNs compares better with that reported for the medulla cells of Papilio than with those reported for the lobula plate cells of the fly or the lobula cells of the locust (Rind, 1990).

The DNs share the characteristic low spatial frequency attenuation of DS cells found in the lamina of the fly (Dubs, 1982) the medulla of the butterfly Papilio (Maddess et al, 1991) and also in more divergent species such as Limulus (Brodie et al, 1978) and in humans (eg Kelly, 1979). For a motion detecting system low spatial frequency attenuation is advantageous because it blocks the dc or zero-movement cues. These are readily transmitted by the optics of the compound eye and produce greater Fourier power but are of limited use in detecting the displacements likely to occur during flight (Dvorak et al, 1980). At high levels of luminance the movements of flies, for example, seldom displace the visual scene by $>10^{\circ}$ (Reichardt and Poggio, 1976). By calculating the signal spectra generated by a moving random pattern, Srinivasan and Dvorak (1980) found that for the normal displacement expected of a fly the optimal spatial frequency would be between $0.05-0.1 \mathrm{cpd}$. Thus the low spatial frequency roll-off shown by the insect motion pathway suggests that the mechanisms which filter and process signals optimise the spatial frequency range for the most usual displacements made. 
One explanation that can be offered for the different spatial frequency sensitivities of the DS cells of the medulla, lobula and ventral nerve cord might be that they are due to interspecific differences. This would simply imply that the peripheral filtering along the pathways of the honeybee and the butterfly removes much more of the low spatial frequency information than filtering along the pathway of the fly and the locust. If species differences are ignored it might be conjectured that more than one motion pathway conveys information through the optic lobes to the central brain. These parallel pathways display different filtering properties: one does not remove low spatial frequencies, as illustrated by the CSF of lobula plate giant cells, the other pathway includes stronger lateral inhibitory interactions producing the low spatial frequency roll-off of the CSF displayed by medulla cells. The DNs might then receive inputs from the pathway with the tighter lateral inhibition, perhaps from analogues of the medulla cells in Papilio.

The sensitivity of the DNs to gratings of different spatial frequencies was examined at different drift velocities. The DNs are most sensitive to movement when it generates a temporal frequency (or contrast frequency, CF) of 8-11 Hz (Ibbotson and Goodman, 1990; see also figs 7-8). Maximum contrast sensitivity is higher for gratings in the CF range $11-16 \mathrm{~Hz}$ (eg fig 8). At CFs $<11 \mathrm{~Hz}$, peak sensitivity shifts to higher spatial frequencies. This is demonstrated by the progressive sensitive cell, DNIV $_{1}$ and the regressive cell DNV $_{1}$ (fig 7b).

In summary, the DNs all respond maximally to wide-field motion over the compound eye; their responses are directionally selective with fairly broad tuning; are CF-dependent; non-habituating and adapt to continued motion stimuli in a way that depends upon CF (Fletcher, 1984; Pomfrett, 1987; Ibbotson, 1989; Goodman et al,

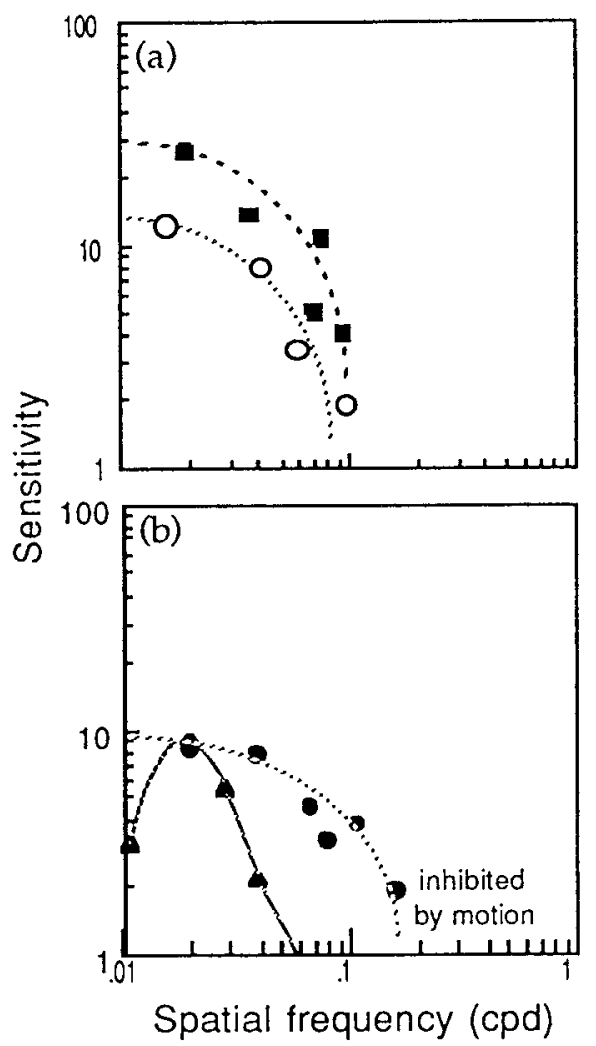

Fig 7. Contrast sensitivity functions for 2 horizontally sensitive cells for gratings moving over the frontal region of the field. (a) The sensitivity of DNIV , to gratings generating $\mathrm{CF} 3 \mathrm{~Hz}$ (circles) and CF $11 \mathrm{~Hz}$ (squares). (b) The sensitivity of $\mathrm{DNV}_{2}$ to gratings generating $\mathrm{CF} 3 \mathrm{~Hz}$ (circles) and $\mathrm{CF} 114 \mathrm{~Hz}$ (triangles).

1987, 1990). In addition, the tuning of their directional responses is biased along one of the orthogonal orientations aligned to the vertical and horizontal. The DNs tend to display similar spatial frequency sensitivities; and their response depend upon the luminance contrast of the stimulus, 


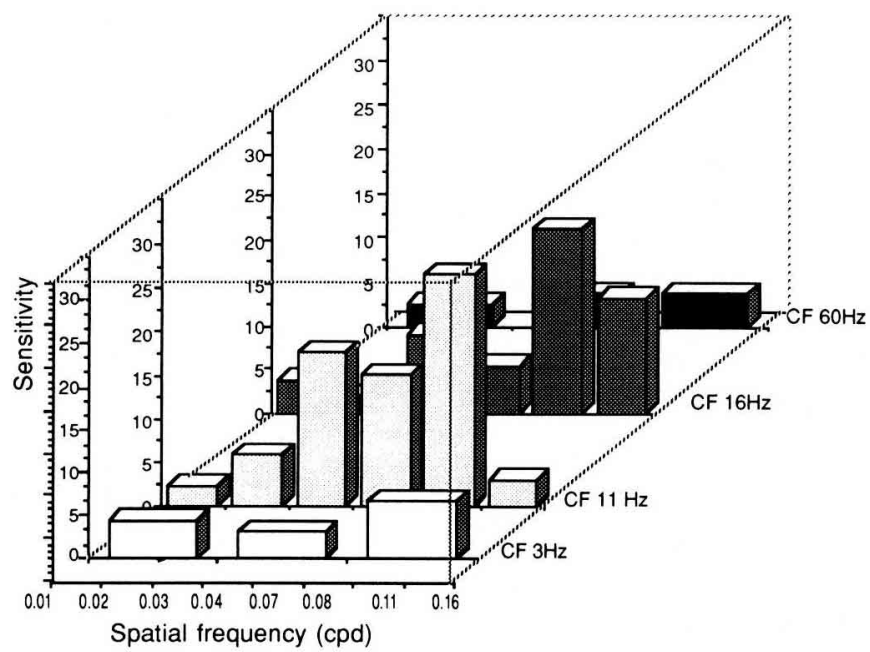

Fig 8. The spatial temporal sensitivity surface of $\mathrm{DNII}_{2}$ shown by the relationship between spatial and temporal sensitivity functions for gratings moving upwards over the frontal regions of the compound eyes. Each row plotted is the sensitivity to motion as a function of spatial frequency found at one of 4 different temporal frequencies.

which in most cases increases as a function of $\mathrm{\partial l}^{2}$. On the basis of behavioural experiments the pathway thought to subserve the optomotor response also displays these features. Optomotor responses are compensatory so that the following movements of the head and/or body tend to reduce wide-field optical flow over the retina. Freely flying honeybees elicit such compensatory movements provided that motion fills enough of their visual field and the motion is within a certain range of speeds. Flying bees will follow moving patterns upwards or downwards, to the left or to the right, about their longitudinal or dorso-ventral axis, depending upon the degree of motion experienced (eg Srinivasan and Lehrer, 1984). The optomotor yaw response of tethered bees has been measured (Künze, 1961) and co- incides with the temporal frequency domain of the responses of the DNs.

\section{ARE THERE DIFFERENCES IN THE PROPERTIES OF THE DNS THAT INDICATE THAT THEY MIGHT BE TRIGGERED BY SPECIFIC OPTICAL FLOW TEMPLATES?}

There is no distinct fractionation of the spatial and temporal frequency ranges of the DNs; however certain properties suggest that the DNs differ in their sensitivity to contrast and motion information. For example, one cell, DNIII ${ }_{4}$, displays greater sensitivity to high spatial frequencies. Its directional properties recommend it for a role in the control of translatory flight speed and it appears to show a relatively greater re- 
sponse to higher contrast frequencies than the other DNs (Ibbotson, 1991). This might indicate a distinction between pathways implicated in different aspects of visually mediated flight control (eg Srinivasan et al, 1993).

It has been suggested that the wide extent of an insect's field of view $\left(313^{\circ}\right.$ around the horizontal plane of the honeybee: Seidl and Kaiser, 1981) allows the detection of optical flow templates which may occur at certain locations and which correspond to specific types of self and object motion (Horridge, 1992). Certain behaviours exhibited by insects do suggest that they might be triggered by specific sorts of optical templates, for example, detecting targets which elicit responses such as landing (eg Musca: Wagner, 1982) chasing (eg tsetse fly: Brady, 1991) or escape (eg Musca: Holmqvist and Srinivasan, 1991). It is legitimate to ask whether the properties of the DNs provide some evidence for the detection of specific optical flow templates. As output neurons they are probably the point(s) of convergence for the neural substrate underlying different motionsensitive behaviours and as such should form a good probe to enquire about the substrate(s) which extract specific features from image flow.

Two stimulus regimes have been used to examine whether the DNs have the capacity to extract specific types of information from the motion of the visual surround and whether this sort of information could indicate particular flight scenarios. The first stimulus regime simulated motion over the lateral regions of the eyes. Synchronous motion of gratings in similar or opposite directions were used to mimic the optical flow consistent with roll, pitch and yaw (Pomfrett, 1987). This revealed that the DNs were tuned to particular sorts of simulated motion (Goodman et al, 1990; Ibbotson, 1990, 1991; Ibbotson and Goodman, 1990). Some neurons respond preferential- ly to upward or downward motion over the frontal region of the eyes, which would enable them to signal deviations in pitch or altitude, for instance if the honeybee were to involunatarily dive or lift (eg DNI; fig 1b). Other DNs also respond to vertical motion, but are more sensitive to upward or downward motion in opposite directions over the lateral regions of the eyes and are therefore suitable for reporting rotations about the longitudinal body axis, for instance during roll (eg $\mathrm{DNIV}_{2}$; fig 1a,b). Some of the DNs respond maximally to rotations about the dorso-ventral axis of the bee (eg DNVII; fig 1d). This sort of horizontal selectivity yields the capacity to signal motion in the yawing plane, as when deviating from a straight forward course. Yet another DN is sensitive to progressive horizontal motion over the eyes (eg DNIII $;$; fig 1c,d). Such optical flow arises in forward translations and might indicate a role in registering changes in flight speed (Ibbotson, 1991).

The distribution of information conveyed by the DNs in the thoracic ganglia is consistent with the coordinated changes in the muscular activity required for particular sorts of compensatory movements. For instance, DNs sensitive to pitch distribute their information symmetrically to both halves of the pro-thoracic and mesometathoracic ganglia. This permits symmetrical changes by the motor system, and might be analogous to the bilaterally distributed branches of pitch-sensitive neuron, DNM, in the locust (Griss and Rowell, 1986; Rowell and Reichert, 1986). Course deviations rarely have perfect symmetry and the correction of roll (Srinivasan, 1977) and yaw deviations (Götz et al, 1979) require an asymmetrical change in muscular activity on either side of the body. The 3 roll-sensitive DNs confine their arborisations to one half of the thoracic ganglia and as one of them crosses the brain, descending into the thorax on the 
opposite side of the body, each half of the thorax would receive data about roll to the right or to the left. Since each half of the ganglia also receives pitch information, specific types of deviation could be identified by the thoracic interneurons/ motoneuron pool. By comparing the signals derived from both sides, banking turns for instance, could be distinguished from rotation about the horizontal or the longitudinal axes. Correctional movements of the head or whole body, counteracting yaw about the longitudinal axis, also require asymmetrical change in muscular activity on each side of the body (Götz et al, 1979). The arborisations of the yawsensitive DNs are also confined to one side of the ganglia, and again collectively these cells would inform each half of the thorax that course deviation to the right or left had occurred.

\section{DIFFERENT COMBINATIONS OF HORIZONTAL OPTICAL FLOW}

Of 19 physiologically characterised identified DNs, 11 respond preferentially to motion along the horizontal (Bidwell, 1992). A second set of experiments examined the effect of particular combinations of horizontal optical flow (figs 8,9 ). The frontal regions of the visual field were examined since objects are fixated there in honeybees (Lehrer, 1990; Zhang et al, 1990) and this region may be more effective in mediating landing (eg flies: Fischbach, 1983). The regime consisted of the independent stimulation of each eye with horizontally moving gratings. The first 4 stimuli in a sequence of 6 were progressive or regressive motion of gratings over the contralateral and then the ipsilateral eyes. The last 2 stimuli in the sequence simulated contraction and expansion of the flow field from a point in the centre of the monitor. These entailed progressive motion over the ipsilateral eye synchronous with regressive motion over the contralateral eye and regressive motion over the ipsilateral eye synchronous with progressive motion over the contralateral eye respectively. This resembles some of the components of the flow field arising during stable translation when flow occurs between 2 poles of no motion lying at opposite ends of the line of the bee's direction of flight. In forward translation the flow field expands out from the pole in front and contracts into the pole to the rear of the insect. Thus in the frontal region of the visual field optical flow caused by straightforward translation will be in opposite directions either side of a vertical plane formed by the dorso-ventral axis and the anterior-posterior axis of the head. Optical flow expands from a pole in the frontal regions of the field during normal forward flight and is approximately horizontal around the equatorial plane of the eye (Horridge, 1992).

Generally, the horizontally tuned DNs are more sensitive to expanding rather than contracting optical flow in the frontal field. It would seem that collectively the responses of the DNs are better suited to detect templates representing the forward motion of the honeybee. This agrees with the view that the underlying network has evolved to extract information from the optical flow expected for the normal flight of the insect, which for the honeybee is forwards. Like other insects (eg Drosophila: David, 1982) the honeybee promotes a constant preferred angular velocity of progressive optical flow over both eyes by altering the power output of the wings (Esch et al, 1975). This enables the bee to stabilise her forward course and avoid crash landing. It also provides the appropriate optical flow required for searching and scanning and enables the honeybee to maintain a constant body orientation, for example when hovering during fixation of a landing site (eg Wehner, 1981). 
Insects can maintain a constant position in space by using the velocity and position components of the flow field. For example, Trigona guard bees hover when stationkeeping by altering their distance from the hive entrance rather than their orientation relative to it (Zeil and Wittmann, 1989). In flight, honeybees also demonstrate that their forward speed is affected by the velocity of optical flow (Hodson, personal communication). The effect upon the flight speed of bees trained to visit the centre of a spiral pattern (devised by Braitenberg and Taddei-Ferretti, 1966; TaddeiFerretti and Perez de Talens, 1973) depends upon whether its movement creates apparent contraction or expansion. The influence of optical flow upon the honeybee's forward speed is particularly evident for contracting flow at certain velocities (Hodson: personal communication). As the honeybee makes her approach to a landing site, over the last $1 \mathrm{M}$ the optical flow in the frontal field has a mean progressive velocity of $110 \%$ in opposite directions over the fronto-lateral regions of both eyes. Contracting spirals which generate temporal frequencies of $9.5 \mathrm{~Hz}$ and an apparent regressive velocity of $120 \%$ s elicit a dramatic increase in the bee's forward velocity to $250 \%$ s. This suggests that when the bee is flying towards her landing site the preferred progressive motion over the front-lateral regions in each direction is maintained around $100 \%$ s. In general at progressive velocities of around $110 \%$, more of the neurons (DNs, IV $, \mid I X, I I_{1}$ and $\mathrm{III}_{4}$ ) linearly integrate the monocular components of the binocular stimuli in their response to expansion than they do in their response to contraction (eg DNVI fig 9c). When CF is constant, DNVI 1 's linearity for the integration of the monocular components of the expanding stimulus decreases with increasing spatial frequency (or decreasing velocity). Since linearity decreases with CF (or increasing velocity)

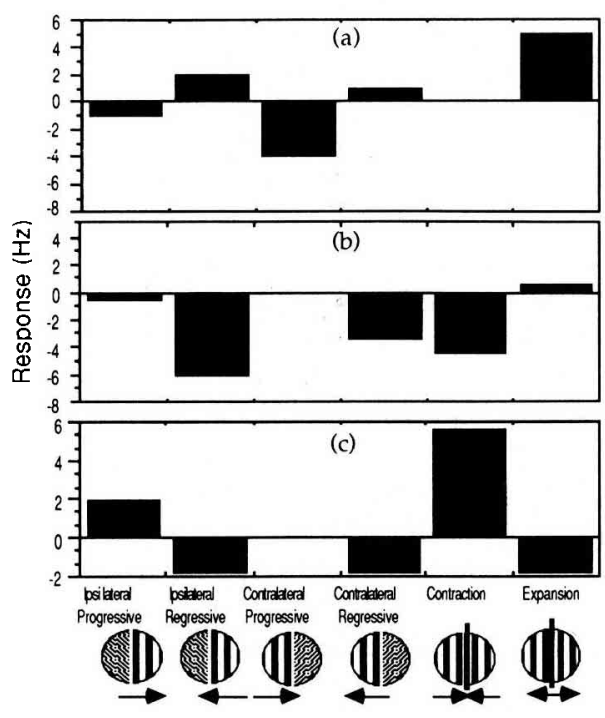

Fig 9. The responses relative to baseline firing of (a) DNIII ; (b) DNV 1 and (c) DNVI to monocular progressive and regressive motion over the ipsilateral and contralateral eyes, and to the binocular combination of these in simulated contraction (ipsilateral regressive and contralateral progressive). and expansion (ipsilateral progressive and contralateral regressive). The spatial and temporal frequency of the gratings were set at the optimum values for the cell responses at $0.019 \mathrm{cpd}$ and $11 \mathrm{~Hz}$ respectively. DNIII ${ }_{4}$ (a) responds more strongly to expansion than expected from the sum of the responses to ipsilateral progressive and contralateral regressive motion. $\mathrm{DNV}_{1}$ (b) responds to expansion and contraction approximately equal to the sum of the responses to the monocular components of

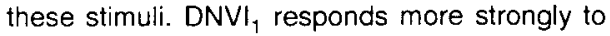
contraction than expected from the sum of the responses to ipsilateral regressive and contralateral regressive motion.

when spatial frequency is constant, this suggests that any velocity dependence occurs only outside the peak CF range, with greater linear integration at low velocities. 
The responses of 2 contralaterally descending cells $\mathrm{DNIII}_{4}$ and $\mathrm{DNVI}$, to the different combinations of horizontal flow have been examined in particular detail. The directional selectivities of these 2 cells suggest that they would be equally suited for the detection of frontal motion information as well as motion over the lateral field. On the basis of their expansion and contraction ratios (figs 8,9 ) $\mathrm{DNs} \mathrm{VI}_{1}$ and $\mathrm{II}_{4}$ represent opposite extremes in the way that they integrate the monocular components of the contracting and expanding stimuli. They also differ in the degree to which spatial and temporal frequency affects the integration of the monocular components of expansion and contraction. Unlike $\mathrm{DNVI}_{1}, \mathrm{DNIII}_{4}$ approximately linearly integrates expansion and inhibits contraction regardless of the spatial or temporal frequency of the stimulating gratings. The binocular integrative properties of $\mathrm{DNIII}_{4}$ for the lateral regions of the eye support it as a candidate cell in the substrate subserving the control of translatory fight (eg lbbotson, 1991). Such a substrate might in turn contribute to the landing scenario in the honeybee. $\mathrm{DNIII}_{4}$ belongs to the only group of cells that demonstrate a selectivity for bilateral progressive motion over the lateral regions of the eye, in contrast to $D N V I_{1}$ for example, which shows a strong response to yaw. Whilst both $\mathrm{DNIII}_{4}$ and $\mathrm{DNVI}_{1}$ descend contralaterally, their anatomy shows them to be very different. For example, $\mathrm{DNVI}_{1}$ has highly diffuse arborisations throughout both sides of the brain whilst $\mathrm{DNIII}_{4}$ restricts its field predominately to a small area on the ipsilateral side. In the thorax, $\mathrm{DNVI}_{1}$ restricts its outputs to one side of the thoracic ganglia and group III DNs extend to cover both sides. Translatory flow might well be integrated by the same neurons that control steering. But under certain circumstances such as landing, an explicit translatory template is essential in order to modulate muscular ac- tivity on each side of the insect symmetrically. Functional specialisation of steering muscles has been clearly demonstrated in studies on Drosophila (Waldvogel and Bausenwein, 1991) and Musca (Egelhaaf, 1989). Different steering muscles mediate different behavioural response components during object orientation, optomotor yaw control and landing and presumably receive inputs from pathways selectively tuned to specific sorts of motion. DNIII ${ }_{4}$ is the only neuron tested which consistently integrates expansion in a nearly linear fashion and strongly inhibits contraction (fig 9a). Thus the overall spatial integration properties of $\mathrm{DNIII}_{4}$ recommend it for a role in landing. The honeybee does not display the stereotypical response of landing as does the fly (Bidwell and Goodman, personal observation), but neither is she constantly airborne. So her deceleration prior to landing might rely on similar optical templates to those that control fly landing. The response associated with landing in flies is reflexive, and released by striped patterns with progressive bilateral motion (Eckert, 1984; Borst and Bahde, 1986, 1987) and centrifugal motion in front of the fly (Goodman, 1960; Perez de Talens and TaddeiFerretti, 1970; Wehrhahn et al, 1981; Eckert, 1984).

An integration model has been proposed to account for landing in flies. It operates upon signals from directionsensitive elementary movement detectors (EMDs: eg Borst and Egelhaaf, 1989), conceivably with the physical identity of those mobilised in optomotor responses (Borst and Bahde, 1986). In this model the output of the EMDs is spatially and temporally summed by a leaky integrator (Borst and Bahde, 1986) and then processed by a threshold device which determines whether landing occurs or not (Borst and Bahde, 1986, 1987, 1988; Borst, 1989; Rees and Spatz, 1989). Pooled spatially, the movement signal increases with the apparent 
size of the landing site or the number of stimulated detectors. Pooled temporally, the landing distance will depend upon the distance from which the fly approaches the landing site. A threshold temporal integrator requires the gradual buildup of signals to a critical value, thus a prerequisite of candidate cells is a gradual rise in firing rate. $\mathrm{DNIII}_{4}$ requires a relatively long time (270 $\mathrm{ms}$ ) to reach $75 \%$ of its maximum firing frequency compared to $\mathrm{DNVI}_{1}$, which reaches the same relative firing level in the shortest time (75 ms). In order to prevent a landing response in mid-air when the integrator is filled, the input channels to the landing integrator should switch themselves off if stimulation is weak. The DNs have been described as either phasic or tonically responding (Bidwell, 1992; Ibbotson, 1992). By extrapolating from the exponential decay of the spike frequency measured in $100 \mathrm{~ms}$ bins to the point where the response is equal to $1 / \mathrm{e} \times$ maximum firing frequency, it was found that $\mathrm{DNIII}_{4}$ was more phasically responding than $\mathrm{DNVI}_{1}$. Thus $\mathrm{DNIII}_{4}$, which adapts to progressive motion much more rapidly (where the exponential decay of the response at $1 / \mathrm{e}$ is $580 \mathrm{~ms}$ ) than $\mathrm{DNVI}_{1}$ (where the exponential decay at $1 / \mathrm{e}$ is 825 ms) would be better suited to playing a role in the integration mechanism which may control landing.

$\mathrm{DNVI}_{1}$ would be better suited to the continual monitoring of optical flow. It has many blebbed outputs in the suboesphageal glanglion where it might directly impinge upon the dendrites of neck motor neurons (eg Pomfrett, 1987). Head movements are often found in the control of yawing deviations in flying insects (eg Hengstenberg et al, 1986; Hensler, 1988; Hensler and Robert, 1990). They are also made by insects when extracting distance information (eg locust: Wallace, 1959; Collett, 1978; Collett and Patterson, 1990; crickets: Goulet et al, 1981). Honeybees can use motion parallax in figure-ground discrimination to detect a landing site (Srinivasan et al, 1989). Thus it is possible that the response of $\mathrm{DNVI}_{1}$ might detect a template used to modulate the orientation of the head towards the sort of motion border which indicates the edge of a landing site. In this sense this would reflect the inclusion of information processed by a motion parallax subsystem.

Motion parallax can reveal information about the structure of the world (eg Lehrer et al, 1988) which is essential to the honeybee in the visual mediation of translatory flight. The velocity profile of the honeybee's world as she flies is 'inhomogenous' (Buchner, 1984). The component retinal velocities generated in forward flight differ in their direction and size with respect to the parts of the eyes subtending them and due to the distance of objects from the bee and their distribution in the scene. This means that mechanisms which control translatory movements must also incorporate information about the location of the locally defined vectors (Collett, 1980). The second operating rule for optomotor control proposed by Collett (1980) suggests that the control of forward thrust might be accomplished by a separate optomotor pathway to the classical one which compensates for changes in flight course. If this is the case then it is possible that some of the DNs might receive optomotor information via different processing pathways. There is a degree of individuality for the different DN with respect to how their responses to the combinations of horizontal flow are integrated between the 2 eyes and how they depend on spatial

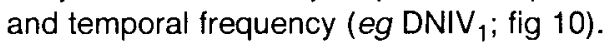
The DNs also display heterogeneity in other details of their characteristics, for example the time courses of their responses (figs $2 b, 3 b, 4 b$ ) and in some cases their contrast characteristics (fig $5 a-c$ ). It is thus conceivable that some of the indi- 


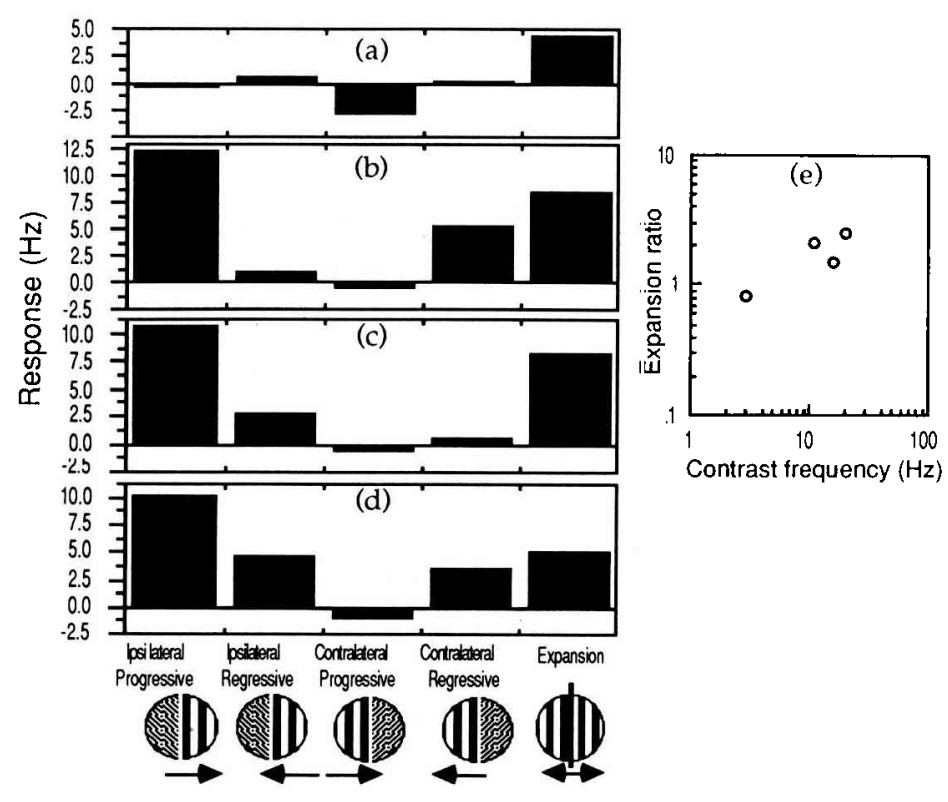

Fig 10. The responses of $D N I V_{1}$ to monocular progressive and regressive motion over the ipsilateral and contralateral eyes, and to the binocular combination of ipsilateral progressive and contralateral regressive in simulated expansion. The spatial frequency of the gratings was set at the optimum value of $0.019 \mathrm{cpd}$. The temporal frequency (CF) of the gratings was varie: (a) $3 \mathrm{~Hz}$; (b) $11 \mathrm{~Hz}$; (c) 16 $\mathrm{Hz}$; (d) $20.5 \mathrm{~Hz}$. The response to expansion relative to the response to the monocular components decreases with increasing CF. This is shown by plotting the expansion ratio as a function of CF (e) where:

Expansion ratio $=\frac{\text { Absolute response to ipsilateral progressive }+ \text { absolute response to contralateral regressive }}{\text { Absolute response to binocular expansion }}$

Values approximating to 1.0 describe a spatially linear relationship between the response to expansion and the sum of the monocular responses. Values $>1.0$ demonstrate how the response to the monocular components of expansion is suppressed when they are presented together (see legend to figure 9).

vidual characteristics of the DNs reflect access to features coded previously along pathways parallel to the classic optomotor pathway. Résumé - Les fonctions possibles
d'une population de neurones descen- dant de la voie optomotrice de l'abeille, Apis mellifera L. L'abeille possède plus de 20 inter-neurones descendants (DNs), qui donnent des réponses sur la direction de mouvements à champs larges se produisant au-dessus des yeux composés. Les caractéristiques des réponses de neu- 
rones individuels identifiés ont été étudiées à l'aide de grilles à ondes carrées déplacées mécaniquement ou de grilles à ondes sinusoïdales synthétisées électroniquement sur un moniteur $X-Y$.

La direction du mouvement préférée des DNs peut être décrite comme étant vers l'avant, vers l'arrière, vers le haut ou vers le bas (fig 1, 3, 4). La division physiologique entre cellules sensibles à la verticalité et cellules sensibles à l'horizontalité peut être corrélée avec certaines caractéristiques anatomiques. II existe 2 groupes distincts de neurones descendants dans le cerveau. Dans chaque groupe, certains DNs préfèrent le mouvement vertical, d'autres le mouvement horizontal. La localisation dans le thorax et la structure des extrémités des cellules sélectives de la verticalité suggèrent que la connection optomotrice de l'information verticale est plus directe que celle de l'information horizontale. Le maintien de la sélectivité verticale et horizontale à travers le cerveau jusqu'au thorax permet également d'intégrer de façon souple l'information provenant des 2 canaux. Cela peut expliquer la large gamme des spectres de réponse des DNs. Des cellules à spectre étroit ont besoin de plus de temps pour arriver au niveau de réponse maximale que des cellules à spectre large (fig 2b).

La réponse des DNs dépend du contraste de luminance, et elle augmente en fonction de dl2 (fig $5 a$, b). Les fonctions de sensibilité au contraste (CSFs) ont été utilisées pour déterminer l'étendue des fréquences spatiales que le système utilise pour coder le mouvement. Les optimums de fréquence spatiale pour le déplacement des grilles de fréquence temporelle optimale se situent entre 0,03 et 0,06 cycles par degré (fig 6b). Cette étendue est comparable à celle des optimums de fréquence spatiale pour les cellules analysées auparavant dans la voie visuelle d'insectes tels que les mouches ou les papillons.
Pour une luminance moyenne plus faible la fréquence spatiale du pic prend des valeurs plus faibles (fig 6b). Pour des fréquences temporelles plus faibles, la sensibilité du pic passe à des fréquences spatiales plus élevées (fig $7 \mathrm{~b}$ ).

L'examen des réponses des DNs aux combinaisons de mouvement dans les différentes directions au-dessus de chaque œil suggère qu'elles transmettent des motifs spécifiques. Les grilles à ondes carrées ont été utilisées pour imiter le flux optique conformément au roulis, au tangage ou aux embardées. Cela montre que les DNs sont sélectifs vis-à-vis de types particuliers de mouvement. Certains détectent des déviations dans le tangage ou l'altitude, d'autres des déviations dans l'axe longitudinal du corps pendant le roulis, et d'autres encore répondent le plus aux déviations de l'axe ventro-dorsal comme dans une embardée.

Les 11 DNs sélectifs de l'horizontalité présentent des différences dans leurs réponses à diverses combinaisons de flux horizontal. Is n'intègrent pas le flux horizontal au-dessus des 2 yeux de la même façon, et varient aussi en ce qui concerne le nombre de fois où l'intégration dépend de la fréquence spatiale et temporelle (fig 9 et 10). La cellule $\mathrm{DNII}_{4}$, par exemple, intègre les composantes monoculaires du flux en expansion de façon à peu près linéaire mais supprime sa réponse aux composantes monoculaires du flux en contraction lorsque les 2 flux se présentent ensemble. Cela se produit quelle que soit la fréquence spatiale ou temporelle. Ses propriétés d'intégration spatiale globale, plus sa distribution symétrique de l'information dans le thorax suggèrent qu'elle a un rôle dans le comportement d'atterrissage. Les DNs présentent une hétérogénéité dans les autres caractéristiques, par exemple le temps de réponse (figs $2 b, 3 b$ et $4 b$ ) et, dans certains cas, leurs caractéristiques de contraste (fig $5 \mathrm{a}-\mathrm{c}$ ). Cela suggère 
que les DNs individuels ont accès à des motifs codés auparavant le long des voies parallèles à la voie optomotrice classique.

neurone descendant / vision / sensibilité au mouvement / sélectivité de la direction

\section{Zusammenfassung - Mögliche Funk- tion einer Population absteigender Neu- rone in der optomotorischen Leitungs- bahn der Honigbiene, Apis mellifera. Die Biene verfügt über mehr als 20 abstei- gende sensuelle Interneurone (DNs), die selektiv gerichtet auf großflächige Bewe- gungen reagieren. Die Reaktionseigen- schaften individueller Neuronen wurden untersucht, wobei entweder mechanisch bewegte rechteckig oder sinusförmig mo- dulierte Streifenmuster benutzt wurden, die elektronisch auf einem X-Y-Schirm er- zeugt wurden.}

Die bevorzugten Bewegungsrichtungen der DNs können als progressiv, regressiv, aufwärts oder abwärts beschrieben werden (Abb 1, 3 und 4). Die physiologische Einteilung in vertikal- oder horizontalempfindliche Zellen kann mit bestimmten anatomischen Merkmalen korreliert werden. Zwei deutlich abgegrenzte DNGruppen sind im Gehirn vorhanden. In jeder Gruppe treten Neurone auf, die bevorzugt auf vertikale oder horizontale Bewegungen reagieren. Die Lage und Struktur der Endigungen der vertikalabgestimmten Zellen im Thorax legt die Vermutung nahe, daß die visuellmotorischen Verbindungen für vertikale Bewegungsinformationen direkter sind als diejenigen für horizontale Informationen Die Beibehaltung der Richtungsselektivität für vertikale und horizontale Bewegungen vom visuellen System bis zum Thorax ermöglicht eine flexible Integration der Bewegungsinformationen. Die breite Richtungsselektivität der DNs und ihre Reprä- sentation in nur zwei Kanälen könnte von Vorteil sein. Eng abgestimmte Zellen benötigen nämlich längere Zeit, um maximal zu reagieren, als breiter abgestimmte Zellen (Abb 2b).

Die Antwort der DNs hängt vom Helligkeitskontrast ab. Gewöhnlich nimmt die Reaktion als eine Funktion von dl2 zu ( $\mathrm{Abb}$ $5 a, b)$. Funktionen der Kontrastempfindlichkeit (CSFs) wurden benutzt, um die Empfindlichkeit der Neuronen für verschiedene räumliche Frequenzen der Streifenmuster zu bestimmen. Bei bester zeitlicher Frequenz $(11 \mathrm{~Hz})$ liegen die Optima für verschiedene räumliche Frequenzen sich bewegender Streifenmuster zwischen 0,03 und 0,06 Umwendungen per Grad (Abb $6 b)$. Diese Bandbreite steht in guter Übereinstimmung mit den Optima der Raumfrequenzen von Zellen, die früher im visuellen System anderer Insekten wie Fliegen und Schmetterlingen gefunden wurden. Bei niedrigerer mittlerer Helligkeit wird das Optimum für Raumfrequenzen zu niedrigeren Werten hin verschoben (Abb 6b). Bei niedrigeren zeitlichen Frequenzen wandert der Gipfel der Empfindlichkeit zu höhören räumlichen Frequenzen (Abb $7 \mathrm{~b}$ ).

Die Antworten der DNs auf Kombinationen von Bewegungen in verschiedenen Richtungen legen nahe, daß die DNs auf spezifische Grundmuster von Bewegungsreizen reagieren. Rechteckförmige modulierte Streifenmuster wurden benutzt, um die optischen Grundmuster zu simulieren, die bei Bewegungen des Tieres während des Rollens, Neigens und Gierens (seitliche Versetzung) entstehen. Es zeigte sich, daß die DNs auf besondere Bewegungstypen abgestimmt sind. Einige erkennen Änderungen in der Neigung oder Höhe, einige reagieren auf Änderungen, wie sie beim Rollen um die Körperlängsachse auftreten, und andere reagieren am stärksten auf Abweichungen um die dorsoventrale Achse wie beim Gieren. 
Die 11 horizontal-abgestimmten DNs zeigen Unterschiede in ihrer Antwort auf unterschiedliche Kombinationen der Horizontalen Bewegung von Streifenmustern. Sie integrieren die horizontale Bewegung über die beiden Augen nicht in derselben Weise und sie unterscheiden sich auch darin, wie die Integration von räumlicher und zeitlicher Frequenz abhängt ( $\mathrm{Abb} 9$ und 10). Die Zelle DNIII4, zB integriert die monokularen Komponenten eines expandierenden Bewegungsreizes ungefähr linar, aber sie unterdrückt ihre Antwort auf die monokulare Bewegungskontraktion, wenn beide Reize zusammen präsentiert werden. Dies geschieht unabhängig von der räumlichen und zeitlichen Frequenz. Ihre Eigenschaften der räumlichen $\mathrm{Ge}$ samtintegration, zusammen mit der symmetrischen Verteilung der Information im Thorax, legen eine Rolle dieses Systems beim Landeverhalten nahe. Die DNs zeigt Heterogenität bei anderen Merkmalen, zB beim zeitlichen Verlauf der Antwort (Abb $2 b, 3 b, 4 b)$ und in einigen Fällen bei ihrer Kontrastempfindlichkeit (Abb $5 a-c$ ). Dies legt die Vermutung nahe, da $B$ individuelle DNs mit visuellen Neuronen verschaltet sind, die andere Eigenschaften der visuellen Stimuli kodieren und parallel zu den klassischen optomotorischen Bahnen verlaufen.

\section{Absteigende Neurone / Visuelles System / Bewegungsempfindlichkeit / Richtungsempfindlichkeit}

\section{REFERENCES}

Anderson AM (1972) The ability of honey bees to generalize visual stimuli. In: Information Processing in the Visual System of Arthropods (Wehner R, ed) Springer-Verlag, Heidelberg

Bidwell NJ (1992) Response characteristics of motion-sensitive descending neurons in the worker honeybee (Apis mellifera). PhD thesis, London
Borst A (1989) Temporal processing of excitatory and inhibitory stimuli in the fly's landing system. Naturwissenschaften 76, 531-534

Borst A, Bahde S (1986) What kind of movement detector is triggering the landing response of the housefly? Biol Cybernet 55, 5969

Borst A, Bahde S (1987) Comparison between the movement detection systems underlying the optomotor and the landing responses in the housefly. Biol Cybernet 56, 217-224

Borst A, Bahde S (1988) Spatio-temporal integration of motion: a simple strategy for safe landing in flies. Naturwissenchaften 75, 265267

Borst A, Egelhaaf M (1989) Principles of visual motion detection. Trends Neurol Sci 12 (8)

Brady J (1991) Flying mate detection and chasing by tsetse flies (Glossina). Physiol Entomol 16 (2), 153-161

Braitenberg V, Taddei-Ferreti C (1966) Landing reactions of Musca domestica. Naturwissenschaften 53, 155-156

Brodie SE, Knight BW, Ratiff (1978) The spatiotemporal transfer function of the Limulus lateral eye. J Gen Physiol 72, 167-292

Buchner $E$ (1984) Behavioural analysis of spatial vision in insects. In: Photoreception and Vision in Invertebrates (Ali MA, ed) Nato ASI Ser, Plenum Press, New York

Collett TS (1978) Peering - a locust behaviour for obtaining motion parallax information. $J$ Exp Biol 76, 237-241

Collett TS (1980) Some operating rules for the optomotor system of a hoverfly during voluntary flight. J Comp Physiol 138, 271-282

Collett TS, Patterson CJ (1990) Relative motion parallax and target localisation in the locust, Shistocerca gregaria. J Comp Physiol A 169, 615-621

David CT (1982) Optomotor control of speed and height by free flying Drosophila. $J$ Exp Biol 82, 389-392

Dubs A (1982) The spatial integration of signals in the retina and lamina of the fly compound eye under different conditions of luminance. J Comp Physiol 146, 321-343

Dvorak D, Srinivasan MV, French AS (1980) The contrast sensitivity of fly movementdetecting neurons. Vis Res 20, 397-407 
Eckert $H$ (1981) The horizontal cells in the lobula plate of the blowfly, Phaenicia sericata. $J$ Comp Physiol 143, 511-526

Eckert $H$ (1984) On the alignment of movement detectors mediating the landing response in the blowtly, Calliphora enthrocephala. In: Localization and Orientation in Blology and Engineering (Varju, Schnitzler, ed) SpringerVerlag, Berlin

Egelhaaf M (1989) Visual afferences to flight steering muscles controlling optomotor responses of the fly. J Comp Physiol A 165, 719-730

Esch H, Natchtigall W, Kogge SN (1975) Correlations between aerodynamic output, electrical activity in the indirect flight muscles and wing positions of bees flying in a servomechanically controlled wind tunnel. J Comp Physiol 100, 147-159

Fischbach KF (1983) Neurogenetik am Beispiel des visuellen Systems von Drosophila melanogaster, habilitation. Univ Würzburg (referenced in Heisenberg and Wolf, 1984) Vision in Drosophila: Genetics of Microbehavior. Springer-Verlag, Berlin

Fletcher WA (1984) Functional characterisation and anatomical identification of descending neurons in the honeybee, Apis mellifera. PhD thesis, London

Fletcher WA, Goodman LJ, Guy RG, Mobbs PG (1984) Horizontal and vertical motion detectors in the ventral nerve cord of the honeybee, Apis mellifera. J Physiol 351

Frisch von K (1914) Der Farbsinn und Formensinn der Biene. Zool J B Abt Allg Zool U Physiol 35, 1

Goodman LJ (1960) The landing responses of insects. I. The landing response of the fly $\mathrm{Lu}$ cilia sericata and other Calliphorae. J Exp Biol 42, 385-407

Goodman LJ, Fletcher WA, Guy RG, Mobbs PG, Pomfrett CJD (1987) Motion sensitive descending interneurons, ocellar LD neurons in the bee: a neural substrate for visual course control in Apis mellifera. In: Neurobiology and Behaviour of Honeybees (Menzel R, Mercer A, eds) Springer, Berlin, 185-202

Goodman LJ, Ibbotson MR, Pomfrett CJD (1990) Directional tuning of motion-sensitive interneurones in the brain of insect. In: Higher Order Sensory Processing (Guthrie DM, ed) Manchester Univ Press, Manchester
Goodman LJ, Ibbotson MR, Bidwell NJ (1991) Spatial, temporal and directional properties of motion-sensitive visual neurons in the honeybee. In: The Behaviour and Physiology of Bees (Goodman L, Fisher RC, eds) CAB Int, Oxon, UK

Goulet M, Campan R, Lsambin M (1981) The visual perception of relative distance in the wood cricket Nemobius sylvestris. Physiol Entomol 6, 357-367

Götz KG, Hengstenberg B, Biesinger R (1979) Optomotor control of wingbeat and body posture in Drosophila. Biol Cybernet 35, 101-112

Griss C, Rowell CHF (1986) Three descending interneurons reporting deviations from course in the locust I. Anatomy. J Comp Physiol A $158,765-774$

Hausen K (1984) The lobula-complex of the fly: structure, function and significance in visual behaviour. In: Photoreception and Vision in Invertebrates (Ali MA, ed) Nato ASI Ser, Plenum Press, New York

Heisenberg M, Buchner E (1977) The role of retinula cell types in visual behaviour of Drosophila melanogaster. J Comp Phyiol 117, 127-162

Hengstenberg R, Hausen K, Hengstenberg B (1982) The number and structure of giant vertical cells (VS) in the lobula plate of the blowily Calliphora erythrocephala. J Comp Physiol 149, 163-177

Hengstenberg $M$, Sandeman DC, Hengstenberg $B$ (1986) Compensatory head roll in the blowfly Calliphora during flight. Proc $R$ Soc Lond B 227, 455-482

Hensler K (1988) The par intercerebralis neurons $\mathrm{PI}(2) 5$ of locusts: convergent processing inputs reporting head movements and deviations from straight flight. Exp Biol 140, 511-533

Hensler K, Robert D (1990) Compensatory head rolling during corrective flight steering in locusts. J Comp Physiol 166, 685-693

Hertel H, Maronde U (1987) The physiology and morphology of centrally projecting visual interneurons in the honeybee brain. $J$ Exp Biol 133, 301-315

Holmqvist MH, Srinivasan MV (1991) A visually evoked escape response of the housefly. J Comp Physiol A 169, 451-459

Horridge GA (1992) What can engineers learn from insect vision? Phil Trans $R$ Soc B 337 , 271-282 
Ibbotson MR (1989) Directionally selective visual interneurons in Apis mellifera and Paravespula vulgaris: a neural substrate controlling visual orientation. PhD thesis, London

Ibbotson MR (1990) Wide-field motion-sensitive neurons tuned to horizontal movement in the honeybee, Apis mellifera. J Comp Physiol 168, 91-102

Ibbotson MR (1991) A motion-sensitive visual descending interneurone in Apis mellifera monitoring translatory flow-fields in the horizontal plane. J Exp Biol 157, 573-577

Ibbotson MR (1992) Direction-selective neurons with tonic and phasic response profiles contribute to the optokinetic system of Apis mellifera. Naturwissenschaften 79, 467-470

lbbotson MR, Goodman LJ (1990) Response characteristics of four wide-field motionsensitive descending interneurons in Apis mellifera. J Exp Biol 148, 255-279

Kaiser W (1975) The relationship between visual movement detection and colour vision in insects. In: The Compound Eye and Vision of Insects (Horridge GA, ed) Clarendon Press, Oxford, UK

Kaiser W, Liske E (1974) Die optomotoriscen Reaktionen von fixiert fliegenden Bienen bei Reizung mit Spektrallichtern. J Comp Physiol 89, 391-408

Kelly DH (1979) Motion and Vision. II. Stabilised spatio-temporal threshold surface. J Opt Soc Am 69, 1340-1349

Kirchner WH, Srinivasan MV (1989) Freely flying honeybees use image motion to estimate object distance. Naturwissenchaften 76, 281

Künze $P$ (1961) Untersuchung des Bewungungssehens fixiert fliegender Bienen. $Z$ Vergl Physiol 44, 656-684

Laughlin SB (1981) A simple coding procedure enhances a neurons information capacity. $Z$ Naturforsch 36c, 910-912

Laughlin SB, Howard J, Blakeslee B (1987) Synaptic limitations to contrast coding in the retina of the blowfly Calliphora. Proc $R$ Soc Lond B 231, 437-467

Lehrer $M$ (1990) How bees use peripheral eye regions to localize a frontally positioned target. J Comp Physiol 167, 173-185

Lehrer M (1991) Locomotion does more than bring a bee to new places. In: The Behavior and Physiology of Bees (Goodman L, Fisher RC, eds) CAB Int, Oxford, UK, 185-202

Lehrer M, Srinivasan MV, Zhang SW, Horridge GA (1988) Motion cues provide the bee's visual world with a third dimension. Nature (Lond) 332 (24), 356-357

Lehrer M, Srinivasan MV, Zhang SW (1990) Visual edge detection in the honeybee and its chromatic properties. Proc $R$ Soc Lond $B$ 238, 321-330

Livingston MS, Hubel DH (1987) Psychophysical evidence for separate channels for the perception of form, color, movement and depth. J Neurosci 7, 3416-3468

Maddess TM, Dubois RA, Ibbotson MR (1991) Response properties and adaptation of neurons sensitive to image motion in the butterfly Papilio aegeus. J Exp Biol 161, 171-199

McCann GD, MacGinitie GF (1965) Optomotor response studies of insect vision. Proc $R$ Soc Lond Ser B 163, 369-401

Menzel R (1967) Untersuchungen zum Erlernen von Spectralfarben durch die Honigbiene (Apis mellifera). Z Vergl Physiol 56, 22-62

Milde JJ, Strausfeld NJ (1990) Cluster organization and response characteristics of the giant fiber pathway of the blowfly Calliphora erythrocephala. J Comp Neurol 294, 59-75

Perez de Talens, Taddei-Ferretti C (1970) Landing reaction of Musca domestica: dependence on dimensions and position of the stimulus. J Exp Biol 52, 233-256

Pomfrett CJD (1987) Visual motion sensitivity of identified interneurons and neck motor neurons in the honeybee Apis mellifera and certain wasps. $\mathrm{PhD}$ thesis, London

Rees C, Spatz HL (1989) Habituation of the landing response of Drosophila wild-type mutants defective in olfactory learning. $J$ Neurogenet 5, 105-118

Reichardt WE, Poggio T (1976) Visual control of orientation behaviour in the fly. $Q$ Rev Biophys 9, 311-438

Rind FC (1990) A directionally selective motiondetecting neurone in the brain of the locust: physiological and morphological characterization. J Exp Biol 149, 1-19

Rowell CHF, Reichert H (1986) Three descending interneurons reporting deviation from course in the locust. II. Physiology. J Comp Physiol 158, 775-794 
Seidl R, Kaiser W (1981) Visual field size, binocular domain and the ommatidial array of the compound eyes in worker honey bees. J Comp Physiol A 143, 17-26

Srinivasan MV, Zhang SW, Chandrashakera K (1993) Evidence for two distinct movementdetecting mechanisms for insect vision. $\mathrm{Na}$ turwissenschaften 80, 38-41.

Srinivasan MV (1977) A visually evoked rool response in the housefly. Open loop and closed loop studies. J Comp Physiol 119, 10-14

Srinivasan MV, Dvorak DR (1980) Spatial processing of visual information and the movement-detecting pathway of the fly - characteristics and functional significance. J Comp Physiol 140, 1-23

Srinivasan MV, Lehrer M (1984) Temporal acuity of honeybee vision: behavioural studies using moving stimuli. J Comp Physiol 155, 297-312

Srinivasan MV, Lehrer M, Zang SW, Horridge GA (1989) How honeybees measure their distance from objects of unknown size. J Comp Physiol A 165, 605-613

Srinivasan MV, Lehrer M, Kirchner WH, Zhang SW (1991) Range perception through apparent image speed in freely-flying honeybees. Vis Neurosci 6, 519-535

Strausfeld NJ (1984) Functional neuroanatomy of the blowfly's visual system. In: Photoreception and Vision in Invertebrates (Ali Ma, ed) Nato ASI Ser, Life Sci, Plenum Press, New York, vol 74

Strausfeld NJ, Seyan HS, Milde JJ (1987) The neck motor system of the fly Calliphora erythrocephala. I,II. J Comp Physiol 160, 205-238

Strausfeld NJ, Lee JK (1991) Neuronal basis for parallel visual processing in the fly. Vis Neurosci 7, 13-33
Taddei-Ferretti C, Perez de Talens (1973) Landing reactions of Musca domestica: IV.A. Monocular and binocular vision. B. Relationship between landing and optomotor reactions. $Z$ Naturforsch 28c, 579-592

Tyrell S, Owens (1988) A rapid technique to assess the resting tates of the eyes and other threshold phenomena: the modified binary search (MoBS). Behav Res Methods Instr Comp 20(2), 137-141

Wagner $\mathrm{H}$ (1986) Flow-field variables trigger landing in flies. Nature (Lond) 297, 147-148

Waldvogel FM, Bausenwein B (1991) Activity of the flight steering muscles in Drosophila during several flight manoeuvres. In: Proc 19th Göttingen Neurobiol Conf. Thieme, Stuttgart

Wallace (1959) Visual scanning in the desert locust Schistocera gregaria Forskal. J Exp Biol 36, 512-525

Wehrer $R$ (1981) Spatial vision in arthropods. In: Comparative Physiology and Evolution of $\mathrm{In}$ sects (Horridge GA, ed) Springer, Berlin

Wehrer R (1987) Matched filters - neural models of the external world. J Comp Physiol A 101,511

Wehrhahn C, Hausen K, Zanker J (1981) Is the landing response of the housefly (Musca) driven by motion of a flow field? Biol Cybernet 41, 91-99

Zeil J, Wittmann D (1989) Visually controlled station-keeping by hovering guard bees of Trigona (Tetragonisca angustula Apidae, Meliponinae). J Comp Physiol A 165, 711-718

Zhang SW, Xiang W, Zili L, Srinivasan MV (1990) Visual tracking of moving targets by freely flying honeybees. I Neurosci $4,376-$ 386 